\title{
Menakar Hubungan Organisasi dan Publik di Media Baru (Analisis Isi Corporate Tweets Industri Perbankan, Otomotif, dan Telekomunikasi)
}

\author{
Syaifa Tania \\ | Departemen Ilmu Komunikasi \\ Fakultas IImu Sosial dan IImu Politik \\ Universitas Gadjah Mada. \\ Bisa dihubungi melalui email tania.syaifa@gmail.com
}

\section{ABSTRAK}

Corporate Twitter has been chosen as one of organization communication tool to communicate with their strategic public in new media. This condition enables public relations division in organization to run their prime function to building a long-term, mutually beneficial relationship between organization and their public. However, public relations performance in building the relationship is mostly measured only by counting the numbers of account's followers, following, and tweets. To measure relationship, counting the number is just not enough. Therefore, the concept of organization-public relationship is considered to be the ideal indicators to measure. Several concepts such as control mutuality, trust, satisfaction, commitment, and the relationship outcomes is used to be the indicators. This research is done by using content analysis towards corporate tweets from three fields of industries such as telecommunication, banking, and automotive. Result of the research show that new media do not change the way organizations communicate with their public. The relationship between organization and public is still categorized as an exchange relationship and twoway symmetrical model of public relations has not yet been realized. This research illustrates how organizations are using Twitter as a communication and relationship-building tool.

Keywords: public relations, organization-public relationship, corporate tweet

\section{Pendahuluan}

Signifikansi peran public relations dalam organisasi semakin nyata urgensinya dalam kurun beberapa tahun terakhir. Secara umum, kinerja sistem public relations seperti dinyatakan oleh Rus melibatkan dua subsistem utama yang berpusat pada lingkup internal dan eksternal organisasi (Petrovici, 2014: 80). Dalam lingkup internal, public relations bertanggungjawab terhadap proses membentuk dan menjaga hubungan di dalam organisasi sehingga memungkinkan terbentuknya iklim internal yang harmonis, sedangkan di lingkup eksternal public relations bertanggungjawab untuk membentuk hubungan jangka panjang dengan para publiknya.

Hubungan antara organisasi dan publik dimaknai oleh Ledingham dan Bruning (1998) sebagai kondisi yang terjadi antara organisasi dan publik-publik utamanya (key publics) dengan tindakan yang dilakukan oleh satu pihak dapat memengaruhi pihak lain. Perspektif relasional ini sejalan pula dengan definisi konseptual public relations untuk membangun dan menjaga 
hubungan dua arah yang saling menguntungkan (mutually beneficial relationships) bagi organisasi dan publik (Cutlip, Center, dan Broom, 2000).

Seiring perkembangannya, kehadiran media baru memberi warna dalam dinamika hubungan antara organisasi dan publik. Sejumlah kajian secara optimis meyakini bahwa media baru mampu mendukung terciptanya hubungan positif antara organisasi dan publik, serta memungkinkan terwujudnya model simetris dua arah (two-way symmetrical) yang selama ini dianggap utopis dan mustahil diwujudkan (Grunig, 2009; Kelleher, 2007). Optimisme ini menguat seiring meningkatnya penetrasi social media di masyarakat yang memengaruhi dinamika komunikasi dan hubungan interpersonal. Dalam konteks organisasi dan publik, social media memungkinkan organisasi dan publik "bertemu" dalam ruang virtual sekaligus memediasi interaksi di antara keduanya. Konsekuensinya, pola proses komunikasi yang terjadi antara organisasi dan publik pun mengalami perubahan. Bagi publik, kehadiran social media memungkinkan mereka dapat menyampaikan keluhan, pertanyaan, dan opininya secara langsung kepada organisasi dalam konteks real-time. Adapun bagi organisasi, social media tidak hanya berfungsi sebagai media diseminasi informasi yang cepat dan murah, melainkan juga dapat digunakan untuk memelajari tren kompetitor, kondisi pasar, serta memahami keinginan publik.

Pemanfaatan social media oleh organisasi utamanya digunakan untuk menjalin hubungan yang harmonis dengan publik. Di antara beragam platform, Twitter menjadi salah satu kanal komunikasi antara organisasi dan publik. Hingga akhir tahun 2011, penetrasi jumlah pengguna Twitter di Indonesia mencapai lebih dari 49 juta pengguna yang kemudian menempatkan Indonesia sebagai negara dengan jumlah pengguna Twitter terbanyak nomor lima di dunia. Akibatnya, semakin banyak organisasi yang kemudian membuat akun Twitter resmi perusahaan (official corporate Twitter account) untuk berkomunikasi dengan publiknya di media baru.

Terlepas dari fungsi social media sebagai medium diseminasi informasi, tekanan kekuatan social media berpusat pada prinsip kolaborasi, berbagi (sharing), partisipasi, dan pemberdayaan (Vasquez dan Velez, 2011). Social media memberikan peluang bagi organisasi untuk melibatkan publik dalam proses komunikasi yang bersifat dialogis (Rybalko dan Seltzer, 2010). Berangkat dari gagasan-gagasan tersebut idealnya model komunikasi simetris dua arah antara organisasi dan publik dapat terwujud. Akan tetapi, faktanya aktualisasi model komunikasi dua arah yang dimediasi oleh social media tidak dapat diwujudkan dengan mudah. Utopia keseimbangan relasi antara organisasi dan publik perlu dikaji ulang. Sejumlah persoalan baik di tataran publik maupun organisasi berkaitan dengan hubungan di antara keduanya dihadapkan pada sejumlah persoalan yang kompleks.

Pada tataran publik, optimisme terhadap gagasan model komunikasi simetris dua arah pada praktiknya menghadapi sejumlah tantangan. Faktanya, relasi antara organisasi dan publik tidak pernah berjalan seimbang. Proses komunikasi yang disampaikan oleh organisasi dijalankan secara terorganisir baik dalam konteks media tradisional maupun media baru. Kondisi ini berbeda dengan publik dalam media baru yang relatif tersebar (Breakenridge, 2008). Pesan yang disampaikan oleh publik kepada organisasi melalui Twitter dapat saja diabaikan karena prinsipnya organisasi memiliki kuasa untuk menjawab, menyebarkan, atau bahkan mengabaikan pesan tersebut. 
Pada tataran organisasi, pertumbuhan pengguna social media di masyarakat mendorong praktisi public relations memanfaatkan platform tersebut untuk berkomunikasi dengan publik, salah satunya melalui Twitter. Idealnya, penggunaan Twitter oleh organisasi seharusnya tidak semata didasarkan pada tren modernitas usaha saja karena Twitter dapat berguna sebagai platform promosi sekaligus koneksi sosial (Smith, 2010). Meskipun demikian, pengukuran kinerja public relations dalam menggunakan Twitter sebagai media untuk menjalin hubungan dengan publik cenderung masih dilakukan secara terbatas. Hubungan antara organisasi dan publik kerap diukur hanya dengan menggunakan indikator jumlah follower, retweet, listed, dan interaction yang diterima oleh akun Twitter organisasi. Padahal, hubungan tidak dapat diukur hanya dengan menggunakan data statistik saja.

Di luar organisasi, sejumlah ajang penghargaan berupaya menjadi evaluator tambahan dalam menakar hubungan antara organisasi dan publik, salah satunya "Social Media Awards". Akan tetapi, ajang penghargaan tersebut cenderung melakukan pengukuran secara terbatas. Pertama, indikator pengukuran utamanya dihitung dari jumlah percakapan dan brand awareness di antara para user social media. Kedua, ajang penghargaan tersebut cenderung memerlakukan seluruh bidang industri secara seragam tanpa memerhatikan perbedaan karakter antara satu bidang industri dan lainnya padahal dinamika aktivitas public relations yang dilakukan oleh masing-masing industri jelas berbeda. Akibatnya, menakar hubungan melalui data statistik tersebut saja dianggap tidak cukup representatif.

Penelitian ini berupaya menakar hubungan antara organisasi dan publik melalui corporate tweets lima perusahaan dari tiga bidang industri yaitu perbankan, telekomunikasi, dan otomotif sepanjang kurun dua minggu menjelang Idul Fitri 2014. Pemilihan ketiga bidang industri didasarkan pada pertimbangan bahwa bidangbidang tersebut merupakan tiga bidang yang berperan vital bagi aktivitas masyarakat pada kurun waktu objek penelitian. Adapun setiap bidang direpresentasikan oleh masing-masing dua akun Twitter perusahaan yaitu Astra Honda Motor (@welovehonda), BNI (@BNI46), BCA (@HaloBCA), Telkomsel (@Telkomsel), dan XL Axiata (@XL123). Khusus bagi industri otomotif hanya direpresentasikan oleh satu perusahaan karena keterbatasan peneliti menelusuri data tweets perusahaan. Ketiga bidang industri yang menjadi objek kajian dalam penelitian ini seluruhnya merupakan bidang yang aktivitas operasionalnya berperan vital bagi masyarakat khususnya pada momen Idul Fitri.

Sebagai pembeda dari kajian terdahulu, penelitian ini menitikberatkan pada kualitas hubungan yang terbentuk melalui pola interaksi, transaksi informasi, dan kaitan antara organisasi dan publik. Selain dapat digunakan untuk menakar hubungan yang terjadi antara organisasi dan publik di media baru, penelitian ini secara umum turut memaparkan praktik online public relations yang terjadi di Indonesia. Pada akhirnya, hasil analisis diharapkan dapat turut berkontribusi terhadap pengembangan instrumen pengukuran hubungan organisasi dan publik dengan titik tekan yang berbeda sesuai dengan karakter publik serta praktik online public relations setiap bidang industri.

\section{Tinjauan Literatur}

\section{Perkembangan Media Baru dan Tren e-PR Tiga Bidang Industri}

Perkembangan media baru mengubah 
lanskap praktik komunikasi antara organisasi dan masyarakat. Sebagai bagian dari media baru, internet kini menjadi kanal utama yang digunakan masyarakat untuk berkomunikasi. Prinsip interaktivitas yang dimiliki oleh media baru memungkinkan setiap penggunanya terhubung dengan para pengguna lain dalam konteks real time. Dalam konteks dinamika hubungan antara organisasi dan publik, media baru memungkinkan proses interaksi di antara kedua pihak berjalan secara langsung dan dialogis. Public relations sebagai representasi fungsi manajemen komunikasi antara organisasi dan publik (Grunig dan Hunt, 1984) dituntut untuk turut mampu menggunakan media baru sebagai kanal komunikasi dengan publik secara online.

Adopsi media baru sebagai kanal komunikasi menghadirkan tren e-PR dalam fungsi kerja public relations. E-PR dikenal juga dengan istilah PR 2.0 atau public relations generasi kedua (Solis dan Breakenridge, 2009). Public relations dalam generasi ini berpusat pada perkembangan media baru dan peran yang dijalankan dalam proses komunikasi antara organisasi dan publik. Berbeda dengan kerja public relations tradisional yang terkesan berat sebelah, dalam konteks PR 2.0 public relations tidak dapat mengabaikan kehadiran dan kuasa publik dalam media baru. Peran public relations organisasi yang mulanya hanya dianggap sebagai tactical tools untuk memengaruhi koverasi publikasi media berkembang menjadi fungsi manajemen strategis yang bertanggungjawab terhadap keterlibatan berbagai lapisan stakeholder organisasi.

Prinsip dasar e-PR secara umum selaras dengan fungsi utama public relations yaitu untuk membantu tercapainya keseimbangan hubungan jangka panjang antara organisasi dan publik sasaran (Fischer dikutip oleh Petrovici, 2014). Dalam konteks hubungan online, publik memiliki kesempatan untuk berinteraksi dengan organisasi dan memeroleh respon langsung sehingga terdapat peluang kemungkinan terpenuhinya kepentingan kedua pihak. Kinerja public relations dalam konteks e-PR berubah dari proses komunikasi yang mulanya bersifat monolog menjadi dialog (Solis dan Breakenridge, 2009, hal. 2). Berbeda dengan public relations tradisional yang cenderung menerapkan model komunikasi satu arah, interaktivitas yang ada dalam media baru memungkinkan terwujudnya proses komunikasi dua arah. Publik dapat merespon pesan yang disampaikan oleh organisasi melalui media baru secara langsung sehingga dialog antara organisasi dan publik dapat terus menerus diproduksi.

\section{Corporate Twitter dan Kinerja Public Relations}

Popularitas penggunaan social media di masyarakat turut berdampak pada kinerja public relations di era digital. Pada tataran ini, hubungan antara organisasi dan publik dipengaruhi oleh cara public relations membangun dialog. Social media dianggap mampu memediasi proses dialogis antara organisasi dan publik. Prinsip interaktivitas dalam social media memungkinkan setiap penggunanya dapat berbagi informasi melalui akun personal masing-masing. Selain itu, social media juga memungkinkan terbentuknya komunitas-komunitas online di sekitar organisasi sehingga dapat membantu organisasi untuk membangun dan menjaga relasi interpersonal dengan publiknya (Edman, 2010). Di antara berbagai platform social media yang ada, Twitter menjadi media komunikasi yang banyak digunakan organisasi untuk berkomunikasi dengan publik.

Twitter merupakan situs microblogging yang memadukan jejaring sosial, blogging, dan pesan 
dalam satu medium (Miller, 2008). Twitter turut menjadi medium yang memungkinkan terciptanya kebebasan berekspresi bagi setiap penggunanya. Kebebasan ini berada dalam dua tataran yaitu kebebasan berpendapat dan kebebasan untuk memilih akun siapa saja yang akan diikuti (follow) dalam lini masanya. Dalam konteks organisasi dan publik, publik dapat mengikuti akun Twitter resmi organisasi namun organisasi memiliki kuasa untuk mengikuti atau tidak mengikuti balik akun Twitter publiknya. Ketidakseimbangan hubungan ini menyebabkan simetri model komunikasi dua arah antara organisasi dan publik sulit diwujudkan.

Akun Twitter resmi organisasi (corporate Twitter account) secara umum terbagi menjadi dua dimensi utama yaitu identitas dan konten (Edman, 2010). Dimensi identitas mengungkap informasi berupa identitas yang ditampilkan oleh organisasi di laman homepage akun Twitternya. Dimensi konten berpusat pada isi pesan yang disampaikan oleh akun Twitter organisasi melalui tweet-nya. Konten terdiri dari lima sub-dimensi yaitu sumber pengirim tweet, jenis tweet, arah diskusi, isi pesan, serta isu dalam konten tweet.

Pada praktiknya, penggunaan Twitter di kalangan praktisi public relations untuk menjalin hubungan dengan publik hadir bukan tanpa halangan. Idealnya, semakin banyak konten yang bersifat dua arah maka semakin baik pula hubungan antara organisasi dan publik. Dalam konteks media baru konsep publik sendiri agak sulit untuk dijelaskan secara pasti karena media baru memungkinkan siapa pun terlibat dalam diskusi. Akan tetapi, dalam penelitian ini publik dibagi menjadi dua jenis yaitu publik konsumen dan non-konsumen. Publik konsumen merujuk pada pengguna Twitter yang berinteraksi dengan organisasi melalui corporate Twitter dalam diskusi yang berkaitan dengan aktivitas penjualan dan pemasaran produk, sedangkan publik non- konsumen merujuk pada pengguna Twitter yang merespon isu di luar penjualan dan pemasaran produk.

Prinsip interaktivitas dan karakteristik relasi horizontal yang terjadi melalui Twitter melahirkan optimisme di kalangan praktisi public relations. Melalui Twitter, publik dimungkinkan untuk turut berperan dalam mengatur arah jalannya proses komunikasi. Publik memeroleh ruang untuk menyuarakan aspirasinya sehingga diskusi yang terjadi antara organisasi dan publik tidak diciptakan oleh wacana organisasi secara mutlak seperti halnya melalui media konvensional. Kehadiran Twitter menyebabkan publik merasa berdaya (empowered) karena menjadi bagian dari komunitas yang lebih besar. Twitter kemudian tidak lagi menjadi media yang diisi oleh entitasentitas terpisah melainkan menjadi satu populasi yang lebih besar dan saling terhubung. Apabila dimanfaatkan secara optimal, kondisi ini sebenarnya merupakan peluang untuk membangun percakapan, menyebarkan informasi positif, dan menciptakan eksposur yang lebih besar bagi organisasi.

\section{Hubungan antara Organisasi dan Publik di Media Baru}

Peran public relations dalam pendekatan manajemen komunikasi berpusat pada upaya untuk memaksimalkan hubungan antara organisasi dan stakeholder-nya (Clark dalam Goodwin dan Bartlett, 2008). Dalam perspektif manajemen relasional, public relations harus mampu menyeimbangkan kepentingan organisasi dan publik melalui hubungan yang efektif (Center dan Jackson, 1995). Publik kemudian terbentuk sebagai bagian dari stakeholder yang menghadapi persoalan atau memiliki isu dengan organisasi (Grunig dan Hunt, 1984). Mengacu pada gagasan 
Ledingham dan Bruning (2000) perspektif relasional merekonseptualisasikan public relations sebagai fungsi manajemen yang mengubah praktik public relations dari manipulasi opini publik melalui pesan komunikasi menjadi kombinasi pesan komunikasi simbolik dan perilaku organisasi untuk memulai, menumbuhkan, dan menjaga hubungan yang menguntungkan baik bagi organisasi maupun publik. Hon dan Gruning (1999) lebih lanjut menjelaskan bahwa hubungan antara organisasi dan publik terjadi ketika muncul tindakan organisasi yang memiliki konsekuensi terhadap publik atau sebaliknya ketika tindakan publik berdampak pada organisasi.

Konstruksi hubungan antara organisasi dan publik kemudian dilakukan oleh Hon dan Gruning (1999) dengan mengembangkan panduan pengukuran hubungan yang terdiri dari dua jenis hubungan dan empat keluaran hubungan yang diyakini dapat mendefinisikan kualitas hubungan jangka panjang antara organisasi dan publik. Adapun keenam indikator tersebut meliputi exchange relationship, communal relaionship, control mutuality, trust, commitment, dan satisfaction (Hon dan Grunig, 1999). Dilihat dari bentuk hubungannya, Hon dan Gruning (1999) mengidentifikasi dua jenis hubungan interpersonal yang dapat digunakan untuk menilai hubungan antara organisasi dan publik yaitu exchange dan communal relationship.

\section{Metode}

Dinamika hubungan antara organisasi dan publik kian semarak seiring dengan pemanfaatan media baru oleh sejumlah organisasi untuk berkomunikasi dengan publiknya. Kini, hampir seluruh perusahaan berlomba-lomba untuk terlibat menggunakan berbagai platform social media untuk menjalin hubungan yang bermanfaat bagi kedua pihak. Twitter menjadi salah satu kanal social media yang dipilih oleh organisasi untuk berkomunikasi dengan publiknya melalui corporate tweets yang disampaikan oleh akun Twitter organisasi. Melalui corporate tweets tersebut hubungan organisasi dan publik dapat dikaji secara komprehensif. Penelitian ini berfokus pada domain pesan serta menekankan pada hubungan antara organisasi dan publik melalui media Twitter yang dimiliki oleh organisasi. Metode analisis isi kuantitatif kemudian dianggap memiliki kapasitas untuk mengkaji aspek-aspek tersebut secara komprehensif.

\section{Pendekatan Penelitian}

Penelitian mengenai analisis isi corporate tweets untuk menakar hubungan organisasi dan publik dilakukan dengan menggunakan pendekatan kuantitatif. Metode yang digunakan dalam penelitian ini adalah metode analisis isi. Metode analisis isi seperti dinyatakan Holsti (1969) dapat digunakan untuk mengeksplorasi konten media yang bersifat nampak (manifest). Selain itu, penggunaan analisis isi tidak hanya terbatas untuk mengkaji karakteristik konten komunikasi namun juga untuk menarik simpulan mengenai peran komunikator (Wright, 1986). Karakteristik ini sejalan dengan asumsi dalam penelitian ini yang beranggapan bahwa organisasi cenderung memiliki peran yang lebih besar dalam relasinya dengan publik. Lebih lanjut, dengan menggunakan analisis isi, peneliti tidak memaksakan keterlibatan dirinya dengan objek kajian sehingga nantinya tidak memengaruhi hasil penelitian (Berger, 2000). Dalam penelitian ini, analisis isi digunakan untuk merekam isu yang muncul dalam relasi antara organisasi dan publik melalui kecenderungan yang nampak dari 
distribusi frekuensi data temuan.

\section{Populasi}

Penelitian ini dilakukan pada lima organisasi yang bergerak di tiga bidang industri yaitu telekomunikasi, perbankan, dan otomotif. Setiap bidang diwakili oleh dua organisasi, kecuali di bidang otomotif yang hanya diwakili oleh satu organisasi saja. Bidang telekomunikasi diwakili oleh perusahaan XL Axiata (@XI123) dan Telkomsel (@Telkomsel), bidang perbankan diwakili oleh BNI (@BNI46) dan BCA (@HaloBCA), dan bidang otomotif diwakili oleh Astra Honda Motor (@welovehonda). Pemilihan kelima akun Twitter organisasi didasarkan pada pertimbangan representativitas karena seluruhnya merupakan akun dengan tingkat interaksi tertinggi, khususnya dilihat dari jumlah tweet, following account, dan followers.

Dalam penelitian ini, unit analisis yang digunakan adalah tweet. Penelitian ini menggunakan sensus pada konten tweet kelima akun sepanjang tanggal $21 \mathrm{Juli}-3$ Agustus 2014 $(n=433)$. Pemilihan rentang tersebut didasarkan pada pertimbangan bahwa rentang waktu tersebut merupakan periode dengan tingkat traffic tertinggi antara organisasi dan publik karena berdekatan dengan hari raya Idul Fitri. Dalam konteks Indonesia, hari raya Idul Fitri merupakan momen-momen tersibuk bagi masyarakat sekaligus momen dimana putaran uang terjadi dalam jumlah besar dan cepat, sehingga mendorong organisasi untuk semakin gencar mengembangkan relasinya dengan publik.

\section{Uji Reliabilitas}

Uji reliabilitas dilakukan dengan membandingkan setiap kategori komparasi antar coder dengan menghitung koefisien reliabilitas. Ambang batas penerimaan koefisien reliabilitas yang digunakan adalah $70 \%$ dengan indeks reliabilitas yang diperoleh dari rumus Kappa. Dalam penelitian ini, hasil uji intercoder reliability menunjukkan bahwa nilai koefisien reliabilitas yang diperoleh sebesar 0,857. Adapun mengacu pada interpretasi Landis dan Koch yang dikutip oleh Stemler (2001), nilai 0,857 memiliki kekuatan persetujuan yang nyaris sempurna.

Dari seluruh variabel kuantitatif yang diujikan dalam coding sheet ditemukan bahwa 24 variabel memiliki tingkat persetujuan sebesar 100\% dan nilai Kappa sempurna sebesar 1. Sedangkan tiga variabel menunjukkan angka 0,577 (besar) untuk variabel isu umum, nilai 0,861 (nyaris sempurna) untuk variabel exchange relationship, dan nilai 0,718 (sangat besar) untuk variabel communal relationship.

\section{Temuan dan Diskusi}

Kehadiran social media telah merevolusi praktik komunikasi korporat yang dilakukan organisasi. Social media secara cepat mengubah pola distribusi pesan dalam program kampanye public relations dengan tidak hanya menyediakan kesempatan bagi praktik komunikasi korporat secara langsung dan cepat, melainkan juga mengaktualisasikan fungsi dasar peran public relations untuk membangun hubungan dengan publik. Meskipun demikian, anomali atas gagasan tersebut justru banyak ditemukan melalui penelitian ini. Kesetaraan proses komunikasi dua arah antara organisasi dan publik tidak terwujud, bahkan muncul kecenderungan adanya dominasi salah satu pihak. Perbedaan konteks dan karakter ketiga industri yang dikaji dalam penelitian ini menunjukkan adanya pola berbeda terhadap bentuk hubungan organisasi dan publik yang 
dikembangkan.

\section{Industri Perbankan}

Pesatnya pertumbuhan industri perbankan di Indonesia mendorong bidang industri ini berkembang secara kompetitif. Meningkatnya jumlah perusahaan perbankan menyebabkan setiap bank nampak homogen di mata publik konsumen khususnya dilihat dari tawaran produk perbankan yang seragam. Tidak adanya diferensiasi produk perbankan memicu rendahnya tingkat loyalitas publik konsumen. Publik konsumen yang memiliki tingkat loyalitas rendah terhadap suatu bank dapat memilih untuk memindahkan atau mengganti akun ke bank lain demi memperoleh layanan atau keuntungan (benefit) yang lebih baik (Jiang, 2002). Pada titik ini, peran public relations hadir untuk menjalankan fungsi komunikasi antara perusahaan perbankan dan publik.

Hasil olah data terhadap pengukuran hubungan organisasi dan publik menunjukkan bahwa industri perbankan secara umum memenuhi sebagian besar indikator pengukuran kecuali dimensi kepuasan (satisfaction). Dalam dimensi kepuasan, tidak ada satu corporate tweetpun dari industri perbankan yang memenuhi indikator dimensi. Seperti yang telah dipaparkan sebelumnya, dalam dimensi kepuasan publik memiliki peran yang lebih besar dibandingkan organisasi. Publik cenderung berperan sebagai komunikator yang menyampaikan kepuasannya terhadap organisasi, sedangkan peran public relations organisasi cenderung lebih reaktif.

Dua akun corporate Twitter yang digunakan sebagai objek kajian dalam penelitian ini tidak menunjukkan adanya kesetaraan data. Akun @HaloBCA menjadi satu-satunya akun yang menunjukkan dimensi kepercayaan, sedangkan akun @BNI46 sama sekali tidak menunjukkan dimensi tersebut. Akibatnya, generalisasi terhadap industri perbankan secara umum tidak dapat sepenuhnya dilakukan. Perbedaan karakter keduanya sebagai perusahaan BUMN dan nonBUMN diyakini dapat memberi konteks.

Badan Usaha Milik Negara (BUMN) merupakan sektor kunci perkembangan perekonomian negara yang dituntut untuk berperan aktif menghasilkan laba sebesarbesarnya sekaligus sebagai bagian aparatur negara yang dibebani penugasan pemerintah. Bagi perusahaan BUMN, pemerintah menjadi stakeholder utama, selain tentunya publik konsumen perusahaan. Meskipun demikian, peran public relations di perusahaan BUMN dan non-BUMN cenderung ditempatkan pada posisi dan fungsi berbeda. Hasil kajian yang dilakukan oleh Ananto, seperti dikutip oleh Yulianita (2002: 223), menyebutkan bahwa terjadi adanya kesalahan persepsi terhadap profesi public relations di tataran manajemen senior sehingga kerap ditempatkan pada posisi sekunder. Ananto melanjutkan, perusahaan BUMN bahkan kerap menempatkan fungsi public relations pada posisi lain atau bahkan digabung dengan divisi lain seperti sumber daya manusia dan pemasaran (Yulianita, 2002: 224).

Kondisi ini berbeda dengan perusahaan non-BUMN yang cenderung menempatkan public relations pada divisi khusus, serta menempatkannya di level manajerial dan bertanggungjawab langsung kepada dewan direksi perusahaan. Penempatan posisi public relations di level manajerial sekaligus memungkinkan praktisi public relations memiliki kuasa dalam proses pengambilan keputusan. Dalam kondisi yang ideal, kuasa tersebut memungkinkan public relations untuk dapat menyuarakan "suara publik" kepada organisasi 
dan terlibat aktif dalam proses pengambilan keputusan organisasi yang berpihak pada kepentingan organisasi dan publik.

Menakar hubungan organisasi dan publik industri perbankan tidak lepas dari temuan menarik tentang dimensi kepercayaan (trust). Hasil olah data penelitian menunjukkan bahwa industri perbankan merupakan satu-satunya bidang industri yang menunjukkan adanya dimensi kepercayaan dalam corporate tweet-nya. Mengetatnya kompetisi di industri perbankan dan tawaran layanan yang seragam membuat perusahaan perbankan sulit melakukan diferensiasi produk. Akibatnya, kredibilitas reputasi organisasi menjadi aset utama bagi industri perbankan dalam persaingan pasar (Sandin dan Simolin, 2006). Lebih lanjut, dalam kajian yang dilakukan oleh Kim (2001) ditemukan bahwa peran public relations dalam menjalankan fungsi manajemen reputasi berdampak positif terhadap performa finansial organisasi.

Peran public relations untuk membangun kredibilitas tidak lepas kaitannya dari dimensi kepercayaan. Dalam industri perbankan, publik sangat peduli terhadap kredibilitas bank mengingat mereka membutuhkan jaminan atas keamanan investasinya. Akibatnya, kepercayaan publik terhadap perusahaan perbankan berperan penting bagi kelangsungan kinerja perusahaan. Dalam praktik public relations tradisional, public relations perusahaan perbankan menjaga kepercayaan publik dengan melakukan monitoring terhadap publikasi perusahaan di media massa (Merrick, 1986). Seiring kehadiran social media, peran public relations dalam menjaga kepercayaan publik harus diikuti dengan adanya komitmen perusahaan terhadap pelayanan publik. Gagasan ini sekaligus mengonfirmasi pergeseran fungsi public relations seperti yang digagas oleh Grunig dan Hunt (2002) dari manajemen reputasi menjadi manajemen hubungan (relationship management).

Takaran hubungan dalam dimensi komitmen (commitment) menunjukkan bahwa perusahaan perbankan mampu menunjukkan komitmennya kepada publik. Aktualisasi komitmen ditunjukkan melalui pemberian respon terhadap pertanyaan yang disampaikan publik melalui tweet. Pada titik ini, industri perbankan menunjukkan adanya mutualitas kontrol atas proses informasi yang terjadi. Ruang yang disediakan oleh social media bagi publik untuk menyampaikan pendapatnya tidak diabaikan oleh perusahaan perbankan sehingga publik tetap memiliki peran dalam proses komunikasi. Secara sederhana, pemanfaatan corporate Twitter oleh public relations di industri perbankan berhasil merepresentasikan idealitas gagasan Solis (2010) bahwa prinsip komunikasi di social media adalah berbicara "dengan" publik dan bukan "kepada" publik.

Mutualitas kontrol yang terjadi dalam proses komunikasi antara perusahaan perbankan dan publik dalam akun @HaloBCA secara sederhana berhasil memenuhi kriteria Grunig dan Hunt (1984) tentang model komunikasi simetris dua arah (two-way asymmetrical model) meskipun cenderung masih dilakukan secara terbatas. Keterbatasan pertama disebabkan karena gagasan model komunikasi simetris dua arah mendorong adanya perubahan dalam diri organisasi secara internal dimana aspek tersebut tidak dapat dieksplorasi secara komprehensif dalam penelitian ini. Kedua, keterbatasan ditunjukkan melalui sikap public relations organisasi yang cenderung reaktif. Dilihat dari sumbernya, mayoritas corporate tweet berasal dari publik dan berisi pertanyaan mereka tentang layanan perusahaan. Akibatnya, hubungan yang terbangun cenderung berada pada kategori 
exchange relationship sedangkan gagasan utama model komunikasi simetris dua arah berpusat pada hubungan dialogis yang menguntungkan kedua pihak.

Interaktivitas turut menjadi konsep penting dalam mengkaji praktik bermedia baru. Takaran dimensi interaktivitas dalam hubungan antara organisasi dan publik industri perbankan relatif rendah (low interactivity), meskipun secara khusus akun@HaloBCA cenderung seimbang dalam menerapkan prinsip interaktivitas tingkat rendah dan sedang. Perbedaan tingkat interaktivitas di antara kedua perusahaan perbankan utamanya disebabkan karena terdapat perbedaan pola aliran komunikasi yang terjadi. Apabila akun@HaloBCA cenderung seimbang antara praktik distribusi informasi dan merespon pertanyaan publik, maka akun @BNI46 lebih banyak mendistribusikan informasi saja tanpa merespon tweet publik. Akibatnya, dialog antara organisasi dan publik sangat minim ditemukan dalam corporate Twitter @BNI46 sehingga interaktivitas yang terjadi sangat terbatas.

Perbedaan tingkat interaktivitas antara akun@HaloBCA dan @BNI46 kembali dikaitkan dengan status perusahaan BUMN dan non-BUMN. Bagi perusahaan BUMN, fungsi public relations cenderung digunakan sebagai fungsi komunikasi sedangkan perusahaan swasta menempatkan public relations pada fungsi manajerial (Wijaya, 2013). Meskipun fungsi komunikasi secara utuh sesungguhnya dapat dilakukan melalui optimalisasi dialog dengan publik, namun akun @BNI46 memaknai fungsi komunikasi sebagai distribusi informasi seperti halnya model public information (Grunig dan Hunt, 1984). Di sisi lain, meskipun fungsi public relations dalam perusahaan swasta banyak ditempatkan pada tataran manajerial namun bank BCA justru mampu menjalankan fungsi komunikasi secara lebih baik. Keseimbangan pola aliran informasi berupa distribusi informasi dan respon terhadap tweet publik mencerminkan bahwa gagasan komunikasi dialogis lebih besar tercermin di akun corporateTwitter@HaloBCA.

Dilihat dari skala prioritasnya, social media nampak belum ditempatkan sebagai kanal utama bagi industri perbankan untuk berkomunikasi dengan publik. Kondisi ini sejalan dengan hasil kajian PwC Indonesia tahun 2014 yang menyebutkan bahwa hanya $12 \%$ dari publik mereka yang memperoleh informasi perbankan dari social media, sedangkan sumber informasi utama mereka adalah media massa. Meskipun demikian, perusahaan perbankan tidak bisa abai serta tetap perlu melakukan evaluasi dalam hubungan organisasi dan publik. Standar pengukuran hubungan organisasi dan publik melalui corporate Twitter tentunya dapat dikaji dengan menggunakan dimensi pengukuran yang digagas oleh Hon dan Grunig (1999). Meskipun demikian, karakteristik khas industri perbankan mendorong perlunya penekanan terhadap dimensi tertentu dari standar indikator dimensi yang diajukan. Mengacu pada hasil penelitian ini, dimensi kepercayaan (trust), mutualitas kontrol, komitmen, hubungan transaksional, dan interaktivitas menjadi lima dimensi utama yang perlu ditekankan secara mendalam untuk menakar hubungan antara organisasi dan publik industri perbankan.

\section{Industri Telekomunikasi}

Industri telekomunikasi Indonesia berkembang pesat hingga mampu menempatkan Indonesia sebagai pasar potensial bagi para pelaku usaha telekomunikasi. Perkembangan industri telekomunikasi di Indonesia sendiri sejak awalnya tidak lepas dari dinamika kondisi sosial 
politik. Sejak tahun 1961, industri telekomunikasi Indonesia dimonopoli oleh perusahaan BUMN melalui jaringan fixed line. Memasuki era Reformasi, Pemerintah melakukan perubahan terhadap kebijakannya dengan mendorong akselerasi pengembangan fasilitas dan infrastruktur telekomunikasi. Pada tahun 2000, Pemerintah kembali menerapkan kebijakan yang bertujuan untuk menghilangkan kontrol monopolistik, meningkatkan transparansi, dan membuka peluang kerjasama strategis dengan rekanan asing. Pada masa tersebut, deregulasi sektor ekonomi dipengaruhi pula oleh program perbaikan ekonomi yang didukung oleh IMF (PT Telkom Indonesia, 2009).

Pada perkembangannya, pasar industri telekomunikasi Indonesia didominasi oleh tiga perusahaan telekomunikasi seluler yaitu Telkomsel, Indosat, dan XL Axiata. Di antara ketiganya, Telkomsel dan XL Axiata menjadi dua perusahaan yang paling aktif berinteraksi dengan publiknya di social media. Melalui akun @Telkomsel dan @XL123, kedua perusahaan sama-sama menggunakan corporate Twitter sebagai media komunikasi korporat. Dibandingkan dengan industri perbankan, industri telekomunikasi tidak menunjukkan adanya perbedaan pola hubungan yang signifikan di antara kedua akun yang menjadi objek penelitian. Kedua akun cenderung menunjukkan pola yang sama dalam berinteraksi dengan publik sehingga hasil penelitian dapat digunakan untuk memahami pola hubungan organisasi dan publik melalui corporate Twitter secara general.

Mutualitas kontrol menjadi daya tarik social media dalam menciptakan hubungan dialogis antara organisasi dan publik. Akan tetapi, hasil olah data industri telekomunikasi justru menunjukkan bahwa baik akun @XL123 maupun @Telkomsel sama-sama belum menunjukkan adanya mutualitas kontrol dalam corporate tweetnya. Hampir seluruh tweet yang disampaikan berasal dari organisasi dan disampaikan dalam format original tweet. Ruang partisipasi bagi publik untuk terlibat dalam proses komunikasi sangat terbatas hingga gagasan Solis (2010) tentang idealitas social media berbicara "dengan" publik dan bukan "kepada" publik tidak terwujud. Artinya, alih-alih menerapkan prinsip dialogis dalam model komunikasi simetris dua arah, industri telekomunikasi cenderung masih menerapkan prinsip public information dengan menekankan model komunikasi satu arah dari organisasi kepada publik.

Dimensi mutualitas kontrol terbukti berhubungan dengan isu yang disampaikan dalam corporate tweet. Hasil uji korelasi menunjukkan adanya nilai signifikansi sebesar 0,006 ( $\mathrm{n}<0,05)$ sehingga hubungan di antara keduanya signifikan. Dalam industri telekomunikasi, mayoritas tweet yang disampaikan memuat isu promosi dan umum. Corporate tweet dengan muatan isu promosi mungkin tidak mampu mengundang banyak respon dari publik, namun isu umum yang tidak berkaitan langsung dengan kepentingan komersial seharusnya dapat mengundang respon yang lebih besar. Melalui corporate tweet yang memuat informasi non-komersial perusahaan telekomunikasi sesungguhnya telah membuka ruang diskusi dua arah yang tidak berkaitan dengan kepentingan promosional perusahaan.

Temuan menarik dari hasil olah data pengukuran hubungan organisasi dan publik industri telekomunikasi berada pada dimensi kepercayaan (trust), kepuasan (satisfaction), dan komitmen (commitment). Hasil olah data penelitian menunjukkan bahwa tidak ada satu pun corporate tweet yang disampaikan oleh kedua akun industri telekomunikasi memuat ketiga dimensi tersebut. Dalam perhitungan statistik, uji 
korelasi antara ketiga dimensi menunjukkan bahwa terdapat hubungan yang signifikan di antara ketiganya. Akibatnya, ketiadaan satu dimensi diyakini berhubungan dengan kedua dimensi lain.

Signifikansi hubungan juga ditemukan dari hasil olah data antara dimensi mutualitas kontrol dan kepercayaan serta komitmen $(n=0,000<0,05$; $n=0,000<0,05)$. Rendahnya mutualitas kontrol yang diwujudkan melalui ruang partisipasi publik dalam dialog berhubungan dengan komitmen organisasi untuk memberikan layanan terbaik kepada publik. Di sisi lain, rendahnya ruang partisipasi publik berhubungan dengan kepercayaan publik terhadap organisasi. Sementara itu, rasionalisasi atas rendahnya kepuasan publik terhadap organisasi dimaknai serupa dengan kondisi yang terjadi dalam industri perbankan. Sifat alami dimensi kepuasan yang berasal dari publik dan bukan dari organisasi menyebabkan organisasi hanya mampu bersikap reaktif(Edman, 2010).

Pola bentuk keluaran hubungan antara organisasi dan publik industri telekomunikasi menunjukkan adanya kecenderungan bentuk exchange relationship. Hubungan transaksional (exchange relationship) dalam industri telekomunikasi diaktualisasikan dalam bentuk consumer rewards dan tips tentang produk dan layanan yang ditawarkan. Bagi akun @Telkomsel, strategi tersebut merupakan bagian dari churn prevention program yaitu program retensi yang bertujuan untuk mempertahankan loyalitas publik konsumen agar tidak berpindah ke perusahaan kompetitor (Pramesti, 2012).

Komparasi tingkat interaktivitas antara industri telekomunikasi dan perbankan menunjukkan bahwa industri telekomunikasi lebih unggul. Tingkat interaktivitas dalam akun corporate Twitter perusahaan telekomunikasi berada dalam kategori sedang (medium). Interaktivitas tersebut ditunjukkan melalui praktik retweet dan tautan konten visual atau link sebagai informasi pendukung.

Seperti halnya industri perbankan, standar pengukuran hubungan organisasi dan publik melalui corporate Twitter dapat dikaji dengan menggunakan dimensi pengukuran hubungan Hon dan Grunig (1999). Akan tetapi, mengacu pada pola takaran hubungan organisasi dan publik yang telah dipaparkan sebelumnya, penekanan terhadap dimensi mutualitas kontrol, hubungan transaksional, dan interaktivitas perlu mendapat prioritas dibandingkan dimensi-dimensi lainnya.

\section{Industri Otomotif}

Industri otomotif Indonesia menunjukkan adanya tren peningkatan yang konsisten setiap tahun. Pasar industri yang kian kompetitif mendorong organisasi untuk mempertahankan publik konsumennya melalui aktivitas relationship marketing (Palmatier et al., 2006). Dalam kajian public relations, aktivitas relationship marketing erat kaitannya dengan excellence theory yang digagas oleh Grunig (1992). Melalui excellence theory, public relations menjalankan fungsi manajemen yang bertujuan untuk mendukung efektivitas organisasi. Meskipun demikian, upaya untuk mempertahankan publik konsumen dihadapkan pada tantangan tentang ketidakmungkinan (impossibility) organisasi untuk menjalin hubungan personal (one-to-one relationship) dengan setiap publik dalam jumlah besar (Cova dan Pace, 2002). Social media kemudian digunakan oleh industri otomotif untuk menjalin hubungan antara organisasi dan publik industri otomotif.

Berbeda dengan industri perbankan dan telekomunikasi yang menggunakan dua akun 
corporate Twitter sebagai objek kajian dengan harapan dapat menggeneralisir hasil temuan penelitian, industri otomotif hanya diwakili oleh satu akun saja yaitu@welovehonda. Hal ini dilakukan karena tidak ditemukannya data corporate tweet akun perusahaan otomotif lain yang memenuhi kriteria penentuan objek kajian penelitian. Lebih lanjut, akun @welovehonda merupakan akun corporate Twitter teraktif dibandingkan akun-akun perusahaan lain sehingga akun @welovehonda dianggap dapat merepresentasikan industri otomotif secara umum.

Hasil olah data takaran hubungan organisasi dan publik menunjukkan bahwa industri otomotif secara umum memenuhi seluruh indikator dimensi hubungan yang digagas oleh Hon dan Grunig (1999), kecuali dimensi kepercayaan (trust). Meskipun masih dilakukan secara sangat terbatas, namun prinsip mutualitas kontrol telah dipraktikkan oleh industri otomotif melalui akun corporate Twitternya. Bagi industri otomotif, mutualitas kontrol ditunjukkan melalui retweet tweet publik yang disampaikan kepada organisasi. Meskipun demikian, presentase retweet tersebut terbilang masih sangat rendah dibandingkan dengan jumlah total seluruh corporate tweet organisasi. Praktik retweet yang dilakukan oleh industri otomotif hanya sebesar $3 \%$, sedangkan original tweet mencapai $97 \%(\mathrm{~N}=$ 93 tweets), tanpa adanya reply atau mention sama sekali. Sejalan dengan temuan tersebut, aliran informasi yang terjadi sebagian besar berasal dari organisasi kepada publik. Akibatnya, konsep dialog dan komunikasi dua arah belum sepenuhnya mampu diaktualisasikan oleh perusahaan otomotif melalui akun corporate Twitter-nya. Mengacu pada gagasan model public relations Grunig dan Hunt (1984), model public information kembali menjadi pola yang masih diadopsi oleh perusahaan otomotif dalam menjalin hubungan dengan publik.

Cerminan dimensi komitmen ditemukan pula dalam corporate tweet industri otomotif. Mengilas balik paparan sebelumnya, hanya industri perbankan dan otomotif saja yang mampu menunjukkan adanya dimensi komitmen dalam corporate tweet mereka. Meskipun demikian, kedua bidang industri mengaktualisasikan komitmen secara berbeda. Apabila industri perbankan mewujudkan komitmennya dengan merespon tweet publik, maka industri otomotif mewujudkannya melalui ucapan terima kasih kepada publik. Secara ringkas, dapat dikatakan bahwa dalam menunjukkan komitmennya kepada publik melalui corporate Twitter, industri perbankan cenderung bersikap reaktif sementara industri otomotif lebih bersikap proaktif.

Industri otomotif menjadi satu-satunya bidang industri yang mampu menunjukkan adanya dimensi kepuasan (satisfaction) dalam akun corporate Twitter-nya. Meskipun sifat alami dimensi kepuasan sesungguhnya berasal dari ekspresi publik yang disampaikan kepada organisasi, namun alih-alih bersikap reaktif, industri otomotif justru mengambil langkah proaktif. Hasil olah data penelitian menunjukkan bahwa industri otomotif secara proaktif menunjukkan adanya dimensi kepuasan dengan mengucapkan terima kasih atas loyalitas dan dukungan publik terhadap organisasi. Di sisi lain, seperti halnya industri telekomunikasi, industri otomotif juga gagal menunjukkan adanya dimensi kepercayaan (trust) dalam konten corporate tweet yang disampaikan.

Hubungan antara organisasi dan publik industri otomotif seperti halnya bidang-bidang industri lain masih berada dalam kategori transaksional (exchange relationship). Akan 
tetapi, seperti halnya industri telekomunikasi, interaktivitas yang terjadi berada pada kategori sedang (medium interactivity) dengan kecenderungan pola yang serupa yaitu penggunaan fitur retweet dan penautan konten visual atau link sebagai informasi pendukung.

Arti penting social media sebagai media komunikasi dipengaruhi oleh sejumlah faktor, salah satunya adalah perubahan gaya hidup (Khan dan Masqood, 2011). Perubahan ini dipahami oleh industri otomotif dengan mengupayakan penggunaan corporate Twitter secara optimal untuk menjalin hubungan dengan publik. Seperti kedua bidang industri sebelumnya, standar pengukuran hubungan organisasi dan publik melalui corporate Twitter dapat dikaji dengan menggunakan dimensi pengukuran hubungan Hon dan Grunig (1999). Adapun penekanan pola takaran hubungan dapat ditekankan pada dimensi mutualitas kontrol, kepuasan, komitmen, hubungan transaksional, dan interaktivitas dibandingkan dimensi-dimensi lain.

\section{Kesimpulan}

Peran public relations dalam organisasi semakin signifikan dalam kurun beberapa tahun terakhir. Divisi public relations yang mulanya hanya bertanggungjawab untuk menjalankan fungsi komunikasi, kini bertanggungjawab pula untuk menjalankan fungsi manajerial yang lebih strategis. Melihat fungsi public relations dalam pendekatan sistem, public relations bertanggung jawab untuk menjalin keselarasan harmoni antara organisasi dan lingkungannya. Hubungan organisasi dan publik yang harmonis kemudian menjadi tujuan utama aktivitas public relations yang dijalankan oleh organisasi.

Upaya untuk menjalin hubungan yang harmonis antara organisasi dan publik ditempuh oleh organisasi, salah satunya dengan memanfaatkan kanal social media. Di antara beragam platform, Twitter menjadi pilihan para pelaku industri untuk berkomunikasi dengan publik. Hubungan organisasi dan publik secara harmonis diyakini mampu terwujud melalui corporate tweet yang dipertukarkan antara organisasi dan publik. Corporate Twitter diyakini dapat mem-bypass proses komunikasi antara organisasi dan publik yang mulanya berbelit dan memakan waktu lama menjadi lebih cepat dan langsung (direct). Lebih lanjut, kehadiran corporate Twitter diyakini mampu mewujudkan idealitas proses komunikasi antara organisasi dan publik melalui model komunikasi simetris dua arah yang digagas oleh Grunig dan Hunt (1984).

Premis positif yang diyakini oleh sejumlah kajian akan kesetaraan proses komunikasi dalam hubungan antara organisasi dan publik di media baru (Kelleher, 2007; Rybalko dan Seltzer, 2010) justru didobrak habis dalam penelitian ini. Hasil penelitian terhadap lima akun corporate Twitter dari tiga bidang industri berbeda seluruhnya menegaskan bahwa kesetaraan proses komunikasi dalam hubungan antara organisasi dan publik sepenuhnya bersifat utopis. Pun demikian dengan peran public relations yang gagal menunjukkan adanya proses komunikasi dialogis melalui media baru. Secara ringkas, simpulan penelitian ini berpusat pada satu gagasan utama bahwa media baru tidak mengubah cara organisasi berkomunikasi dengan publik.

Aktualisasi praktik online public relations yang diyakini mampu memfasilitasi ruang dialogis antara organisasi dan publik di media sosial tidak terwujud secara utuh. Dari seluruh akun corporate Twitter yang dikaji dari ketiga bidang industri, tidak ada satu akun pun yang mampu menunjukkan adanya dialog yang setara antara organisasi dan publik. Dengan menerapkan indikator pengukuran 
hubungan organisasi dan publik yang digagas oleh Hon dan Grunig (1999), gagasan tersebut dicerminkan melalui hasil olah data terhadap dimensi mutualitas kontrol. Gagasan utama dimensi mutualitas kontrol adalah adanya ruang yang setara bagi partisipasi publik dalam proses komunikasi. Akan tetapi, faktanya proses komunikasi yang terjadi masih didominasi oleh organisasi. Hal ini ditegaskan pula oleh hasil penelitian yang menunjukkan bahwa sebagian besar proses komunikasi yang terjadi melalui corporate tweet berada dalam tingkat interaktivitas kategori rendah dan sedang.

Perbedaan karakteristik tiap bidang industri diyakini pula mampu memberikan konteks yang berbeda dalam penerapan standar pengukuran hubungan organisasi dan publik. Dimensi kepercayaan (trust) hanya mampu direpresentasikan oleh industri perbankan, melalui salah satu akun-nya saja. Penekanan dimensi kepercayaan dalam industri perbankan menjadi sangat wajar mengingat industri perbankan melibatkan aspek investasi material yang besar sehingga kredibilitas reputasi organisasi menjadi aset utama industri perbankan dalam persaingan pasar (Sandin dan Simolin, 2006). Kepercayaan publik terhadap organisasi memiliki hubungan yang signifikan dengan dimensi komitmen. Industri perbankan, melalui salah satu akunnya berhasil menunjukkan adanya dimensi komitmen dalam corporate tweet-nya. Selain industri perbankan, industri otomotif juga mampu mencerminkan dimensi tersebut dalam akunnya. Meskipun demikian, bidang industri yang berbeda di antara keduanya menyebabkan adanya perbedaan pola aktualisasi dimensi komitmen dalam corporate tweet masing-masing. Industri perbankan cenderung lebih reaktif dengan merespon tweet publik, sedangkan industri otomotif cenderung lebih proaktif dengan melakukan compliment kepada publiknya.

Dimensi kepuasan menjadi indikator hubungan yang juga digagas oleh Hon dan Grunig (1999). Meskipun demikian, dimensi kepuasan hanya mampu dicerminkan oleh corporate tweet industri otomotif saja. Bentuk keluaran hubungan turut menjadi indikator yang digagas dalam mengukur hubungan organisasi dan publik. Hubungan organisasi dan publik yang ideal seharusnya berada dalam bentuk communal relationship. Meskipun demikian, hasil penelitian menunjukkan bahwa hubungan organisasi dan publik yang terjadi di corporate Twitter seluruhnya berbentuk exchange relationship.

Sejumlah keterbatasan dalam penelitian ini menyebabkan adanya beberapa aspek yang tidak dapat dieksplorasi secara lengkap. Pertama, kajian hubungan organisasi-publik menitikberatkan pada dua pihak yaitu organisasi dan publik sebagai aktor utama, namun penelitian ini cenderung masih memusatkan fokus kajiannya hanya pada sisi organisasi saja. Kedua, besarnya beban informasi yang diteliti menyebabkan peneliti mengalami kesulitan dalam mengeksplorasi dimensi waktu dalam setiap interaksi yang terjadi melalui corporate tweet.

Menyadari segenap limitasi di atas, maka potensi pengayaan kajian dapat dilakukan dengan mempertimbangkan sejumlah masukan. Pertama, kajian terhadap hubungan antara organisasi dan publik di media baru dapat dieksplorasi lebih lanjut dengan menyandingkan tiga elemen utama yaitu organisasi, publik, dan media sebagai fokus kajian. Kedua, pendalaman fokus kajian dengan membandingkan beberapa organisasi dari satu bidang industri dengan status perusahaan yang bervariasi. Ketiga, memperluas cakupan platform media sosial yang digunakan organisasi. Terakhir, pengembangan instrumen penelitian dengan mempertimbangkan karakteristik khas hubungan 
organisasi dan publik sesuai dengan hasil temuan dalam penelitian ini untuk setiap bidang industri.

\section{Referensi}

Berger, A.A. (2000). Media and communication research methods: An introduction to qualitative and quantitative approaches. London: Sage Publications.

Breakenridge, D. (2008). PR 2.0: New media, new tools, new audiences. New Jersey: FT Press.

Center, A.H., dan Jackson, P. (1995). Public relations practices: Management case studies and problems. Fifth edition. Englewood Cliffs, NJ: Prentice-Hall.

Cutlip, S.M., Center A.H., dan Broom, G.M. (2000). Effective public relations. Eighth edition. Upper Saddle River, NJ: Prentice-Hall.

Cova, Bernard dan Stefano Pace. (2006). Brand community of convenience products: New forms of customer empowerment - the case of "My Nutella the Community". European Journal of Marketing, Volume 40 No. 9/10, hal. 1087-1105.

Edman, H. (2010). Twittering to the top: A content analysis of corporate tweets to measure organization-public relationships. Master Thesis. Lousiana State University.

Goodwin, F.W. dan Bartlett, J.L. (2008). Public Relations and Corporate Social Responsibility (CSR). Working Paper. Terarsip di<http://eprints.qut.edu.au/>.

Grunig, J.E. (2009). Paradigms of global public relations in an age of digitalisation. Prism Volume 6 No. 2

Grunig, J.E., dan Hunt, T. (1984). Managing public relations. New York: Holt, Rinehart \& Erlbaum.

Holsti, O.R. (1969). Content analysis for the social sciences and humanities. Reading: Addison-Wesley.

Hon, L.C., \& Grunig, J.E. (1999). Guidelines for measuring relationships in public relations. Gainesville, FL: Institute for Public Relations.

Jiang, J. (2002). Linking East with West: Websites as a Public Relations Tool for American and Chinese Banks Operating in a CulturallyEvolving Chinese Society. Virginia: Virginia Polytechic Institue and State University. Master Thesis.

Kelleher, T. (2007). Public relations online: Lasting concepts for changing media. California: Sage Publications Inc.

Khan, M.T dan F. Masqood. (2011). Incorporating Social Media into Integrated Marketing Communication of an Organization: The Case of Warid Telecom Pakistan. Swedia: University of Skovde. Master Thesis.

Kim, Y. (2001). Searching for the organizationpublic relationship: A valid and reliable instrument. Journalism\&Mass Communication Quarterly, 84(3), hal. 419438.

Ledingham, J.A., dan Bruning, S.D. (1998). Relationship management in public relations: Dimensions of an organizationpublic relationship. Public Relations Review, 24(1), Hal. 55-65.

Merrick, A.P. (1986). Building a trust fund. Public Relations Journal, Volume 42 No. 9, hal. 21-23.

Miller, V. (2008). New media, networking and phatic culture. Convergence: The Journal of Research into New Media Technologies, Volume 14 No. 4, 387-400.

Petrovici, M.A. (2014). E-Public Relations: Impact and efficiency a case study. Prcedia-Social and Behavioral Sciences, Volume 141, hal. 
79-84.

Palmatier, R.W., Rajiv P.D., Dhruv G., dan Kenneth R.E. (2006). Factors influencing the effectiveness of relationship marketing: $A$ meta-analysis. Jounal of Marketing, Volume 70 No. 4, hal. 136-153.

Pramesti, A.R. (2012). Strategi Marketing Public Relations Telkomsel Surakarta dalam Menjaga Loyalitas Pelanggan. Surakarta: Universitas Muhammadiyah Surakarta. Skripsi.

PT Telkom Indonesia. (2009). Overview of Telecom Industry in Indonesia. Annual Report. Terarsip di <http://www.telkom.co.id /en/investor-relations/laporan-laporan/ laporan-tahunan>.

Rybalko, S., dan Seltzer, T. (2010). Dialogic communication in 140 characters or less: How Fortune 500 companies engage stakeholders using Twitter. Public Relations Review, Volume 36 No. 4, Hal. 336-341.

Sandin, D., dan T. Simolin. (2006). Public Relations As Perceived and Practiced by Commercial Banks. Sweden: Luela University of Technology. Master Thesis.

Smith, B. (2010). Socially distributing public relations: Twitter, Haiti, and interactivity in social media. Public Relations Review, Volume 36 No. 4, Hal. 329-335.

Solis, B. (2010). Engage! The Complete Guide for Brands and Business to Build, Cultivate, and Measure in the New Web. Hoboken, $\mathrm{NJ}$ : John Wiley\&Sons.

Stemler, S. (2001). "An overview of content analysis". Practical Assessment, Research \& Evaluation, Volume 7 No. 17.

Vasquez, L.M.G., dan Velez, I.S. (2011). Social media as strategic tool for corporate communication. Revista Internacional De
Relaciones Publicas, Volume 1 No. 2, Hal. 157-174.

Wijaya, D. (2013). Aktivitas Public Relations di PT KAI DAOP VI. Yogyakarta: Universitas Atma Jaya Yogyakarta. Skripsi.

Wright, C. (1986). Mass communication: A sosiological perspective. Third edition. New York: Random House.

Yulianita, N. (2002). Pengaruh kepemimpinan manajer public relations terhadap kualitas manajemen public relations dan korelasinya dengan efektivitas sistem komunikasi perusahaan. MediaTor, Volume 3 No. 2, hal. 221-240. 